Research Report No. 30/2011

\title{
Debtor Assistance and Debt Advice: The Role of the Canadian Credit Counselling Industry
}

Stephanie Ben-Ishai

Osgoode Hall Law School of York University, sbenishai@osgoode.yorku.ca

Saul Schwartz

Follow this and additional works at: http://digitalcommons.osgoode.yorku.ca/clpe

\section{Recommended Citation}

Ben-Ishai, Stephanie and Schwartz, Saul, "Debtor Assistance and Debt Advice: The Role of the Canadian Credit Counselling Industry" (2011). Comparative Research in Law \& Political Economy. Research Paper No. 30/2011.

http://digitalcommons.osgoode.yorku.ca/clpe/68 


\section{OSGOODE}

OSGOODE HALL LAW SCHOOL

YOR K UN I VERS I T Y

\section{OSGOODE HALL LAW SCHOOL}

Comparative Research in Law \& Political Economy

RESEARCH PAPER SERIES

Research Paper No. 30/2011

\section{Debtor Assistance and Debt Advice: The Role of the Canadian Credit Counselling Industry}

Stephanie Ben-Ishai and Saul Schwartz

Editors:

Peer Zumbansen (Osgoode Hall Law School, Toronto, Director Comparative Research in Law and Political Economy)

John W. Cioffi (University of California at Riverside)

Leeanne Footman (Osgoode Hall Law School, Toronto, Production Editor)

Comparative Research in Law \& Political Economy 
Osgoode CLPE Research Paper 30/2011

Vol. 07 No. 07 (2011)

Stephanie Ben-Ishai and Saul Schwartz

\title{
Debtor Assistance and Debt Advice: The Role of the Canadian Credit Counselling Industry
}

\begin{abstract}
A continuing theme of our work, and that of others, has been the failure of insolvency law to keep pace with the new problems faced by low-income debtors. Researchers have suggested that the cost of personal bankruptcy puts it beyond the reach of many of those in need of it, though it has proven difficult to demonstrate conclusively that large numbers of lowincome debtors would take advantage of bankruptcy if the price was lower. In this paper, we analyze another industry - the not-for-profit credit counselling industry - that has grown rapidly in recent years and that offers a different sort of remedy for financial distress.
\end{abstract}

We begin in Section II with a brief history of the credit counseling industry in Canada and in the US. We show how the industry has evolved from a small set of government-subsidized and community-based not-for-profit groups into an industry that is heavily subsidized by credit suppliers and, for the most part, lacking any significant community connection. In Section III, we briefly set out the regulatory framework that seems to encompass credit counselling agencies ("CCA"), both for-profit and not-for-profit. We do not, however, reach any conclusions on the application of this framework to Canadian CCA. Instead, we describe the concepts underlying the framework in a coordinated way. In Section IV, based on a set of "mystery calls" to the largest CCA, we show that most simply have nothing to offer low-income debtors and that most do not do a good job of providing information concerning the alternatives available to them. Rather than introducing substantive legislative or legal rules to help low-income debtors, the Canadian federal government has chosen instead to promote financial education with its 2010 Task Force on Financial Literacy. In Section V, we briefly analyze the Task Force process, suggesting that it largely overlooked the needs of the poor.

Key words: insolvency, bankruptcy, debt, commercial law, law and finance

Forthcoming in: the Annual Review of Insolvency (2011) 
Debtor Assistance and Debt Advice:

The Role of the Canadian Credit Counselling Industry

\author{
Stephanie Ben-Ishai \\ Osgoode Hall Law School \\ York University \\ Saul Schwartz \\ School of Public Policy and Administration \\ Carleton University
}

October 9, 2011

We would like to acknowledge the financial support of the Social Science and Humanities Research Council and the research assistance of Thomas Baynes, Ashley Butts, Nicole Enouy, Alexandra Kirschbaum, Jennifer Peddar, Rebecca Rui-An Peng, Daniel Schwartz, Nancy Werk and Alla Zhura. 


\section{Introduction}

Past decades have seen a substantial increase in the extent to which people with low incomes have been able to borrow. In countries like Canada, low-income people have increasingly borrowed on their credit cards or through payday lenders.

The opportunity to borrow has brought many benefits, ranging from access to capital to start a small business to an increased ability to work through financial emergencies. At the same time, the opportunity to borrow has also increased the number of low-income people who are heavily in debt and have no realistic possibility of repaying what they owe.

A continuing theme of our work, and that of others, has been the failure of insolvency law to keep pace with the new problems faced by low-income debtors. Researchers have suggested that the cost of personal bankruptcy puts it beyond the reach of many of those in need of it, though it has proven difficult to demonstrate conclusively that large numbers of low-income debtors would take advantage of bankruptcy if the price was lower.

In this paper, we analyze another industry — the not-for-profit credit counselling industry — that has grown rapidly in recent years and that offers a different sort of remedy for financial distress.

We begin in Section II with a brief history of the credit counselling industry in Canada and in the US. We show how the industry has evolved from a small set of government-subsidized and community-based not-for-profit groups into an industry that is heavily subsidized by credit suppliers and, for the most part, lacking any significant community connection.

In Section III, we briefly set out the regulatory framework that seems to encompass credit counselling agencies ("CCA"), both for-profit and not-for-profit. We do not, however, reach any conclusions on the application of this framework to Canadian CCA. Instead, we describe the concepts underlying the framework in a coordinated way.

In Section IV, based on a set of "mystery calls" to the largest CCA, we show that most simply have nothing to offer low-income debtors and that most do not do a good job of providing information concerning the alternatives available to them.

Rather than introducing substantive legislative or legal rules to help low-income debtors, the Canadian federal government has chosen instead to promote financial education with its 2010 Task Force on Financial Literacy. In Section V, we briefly analyze the Task Force process, suggesting that it largely overlooked the needs of the poor.

\section{A Brief History of the Credit Counselling Industry}


Credit Counselling Services of Metropolitan Toronto (CCSMT), which opened in the summer of 1966, was the first not-for-profit CCA in Canada. ${ }^{1}$ At the beginning, CCSMT's only three employees were its executive director, George E. Penfold, one counsellor and a secretary. The fledgling agency had arisen from a committee formed by the Social Planning Council of Toronto in 1965.

According to the Globe and Mail, "[t]he cost of the credit counselling service is borne by the credit-granting business community and the federal and provincial governments." "From the mid-1960s until 1991, the provincial government generally subsidized $60 \%$ of the operating expenses of not-for-profit CCA in Ontario, including CCSMT. ${ }^{3}$ Most of these agencies were based in particular communities and their number grew rapidly, up to 10 in 1973, to 28 by 1978 and to 30 in $1991 .{ }^{4}$ In general, the federal government transferred money to the province to help with the provincial contribution, although the federal percentage varied over time. Ontario CCA also received grants from the United Way. ${ }^{5}$

From the beginning, creditors played several important roles for the CCA. First, they returned to the CCA a small percentage - less than $10 \%$ it seems - of the funds they received as a result of the activities of the CCA. ${ }^{6}$ Second, staff from the creditors took up positions on the boards of directors of the CCA. In addition, the employees of the CCA often had held previous jobs in the credit-granting community. For example, Penfold, the executive director of Credit Counselling Services of Metropolitan Toronto from its inception until the mid-1980s, had previously worked for the Household Finance Corporation; the first CCSMT counsellor had previously been a "credit manager".

The tension between serving poor debtors and collecting outstanding debts for creditors arose almost immediately. This can be seen in an exchange of letters in the Globe and Mail between Moses McKay, a former CCSMT board member, and Penfold. On May 20, 1968, McKay wrote that "... the taxpayers who pay over $80 \%$ through the federal and provincial taxes of the cost of running the Credit Counselling Service should know that this organization resembles a collection agency more than a debt counselling organization."7 The issue that McKay raised was that the clients who were being referred to CCSMT were generally only those who had income beyond that deemed necessary to live at a moderate standard of living and who agreed to use that "excess" income to repay their debts. ${ }^{8}$ Those who either did not have enough money to live on or who would require more than three years to repay their outstanding debts were not helped. In a May 24, 1968 letter responding to McKay, Penfold took issue with the characterization of CCSMT as a "collection agency", citing a Social Planning Council of Toronto document that had

\footnotetext{
${ }^{1}$ Estaban Uribe and Amanda Tait, "Credit Counselling: A Way Forward” The Public Interest Advocacy Centre(30

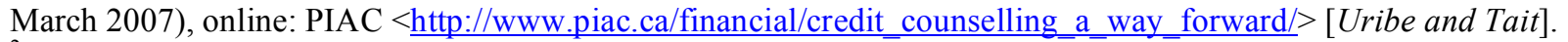

2 "Metro Credit Counselling opens centre tomorrow" Globe and Mail (20 September 1966) p. 11.

3 "A decade of debt lies ahead" Globe and Mail (9 May 1980); Warren Potter "Budget now for Christmas" Toronto Star (10 December 1985) ES12; Ellen Roseman, "Credit counsellors face money worries" Globe and Mail (23 November 1991) B6.

${ }^{4}$ Reports of the Ministry of Community and Social Services, various years.

5 Ellen Roseman, "Credit counsellors face money worries" The Globe and Mail (23 November 1991$)$ B6.

${ }^{6}$ Ibid.

7 Moses McKay, "Credit Counselling" Globe and Mail (20 May 1968).

8 Ibid.
} 
concluded that the CCSMT was a "valuable and useful service". 9 The exchange ended with McKay writing back on May 30, 1968 that Penfold's point was irrelevant as long as CCMST was refusing to help those who had no means to repay their debts. ${ }^{10}$ The exchange between McKay and Penfold has remained relevant to this day. We argue below that modern CCA provide little help to those who are unable to enter a debt management plan.

In the fall of 1991, the New Democratic Party government of Bob Rae announced that it was ending its subsidy of the CCA. ${ }^{11}$ In the legislature, the Minister of Community and Social Services argued that creditors needed to play a larger role in financing credit counselling. ${ }^{12}$ This unexpected announcement forced the CCA to either close or find other sources of funds. The identity of the "other source of funds" rapidly became clear as creditors took the place of the provincial government as the major source of revenue for the CCA. The reliance on funding from creditors should have immediately raised questions about how the CCA were to manage the now increased tension between serving the interests of clients - handling their debts in the most effective way - and serving the interests of its funders - collecting as much as possible on the debts owed. In retrospect, it seems naïve for the Minister to have believed that a major change in funding would not lead to a major change in the character of the CCA.

In 2005, the CCA landscape was greatly altered by the start-up of InCharge Debt Solutions Canada (IDS), then a subsidiary of the Florida-based InCharge Debt Solutions. ${ }^{13}$ Following the "new school" US credit counselling model, IDS works with clients almost exclusively over the telephone. By contrast, the Credit Counselling Service of Metropolitan Toronto (which now operates under the name of Credit Canada) runs several centres in the Greater Toronto Area (GTA) where clients can receive in-person counselling if they so choose. IDS operates out of a small office park in suburban Mississauga, in offices well-equipped for telephone counselling but without much space for in-person counselling. In 2006, a second "new school" credit counsellor - Consolidated Credit Counseling Services of Canada (CCCS) — set up operations in the GTA. "Where Credit Canada once had the GTA "market" to itself, it now faced two strong competitors who seem heavily focused on setting up and administering debt management plans, relegating other activities to a secondary role. Neither IDS nor CCCS has any visible

\footnotetext{
9 G. E. Penfold, "Credit Counselling” Globe and Mail (24 May 1968).

${ }^{10}$ Moses McKay, "Credit Counselling” Globe and Mail (30 May 1968).

11 "Credit advice trimmed" Globe and Mail (9 November 1991) A7.

${ }^{12}$ See Ontario, Legislative Assembly, Official Report of Debates (Hansard), 35th Parl, 1st Sess, Vol A (19

December 1991) at 1450 (Hon Mrs Boyd), online: < http://hansardindex.ontla.on.ca/hansardeissue/35-1/1102a.htm>. The Minister also pointed out that cuts to federal funding for social programs made the action necessary. In addition, she hoped that "the federal bankruptcy bill" would mandate creditor contributions.

${ }^{13}$ IDS is no longer formally associated with its Florida-based parent. Nonetheless, at least two of its board members are intimately involved with the Florida version of IDS. Moreover, IDS Canada returns 20\% of its revenues to IDS Florida in return for using the IDS name and for the initial set-up funds. (2008 IDS Annual report).

${ }^{14}$ Based only on the strong similarity between their websites, we speculate that CCCS is related to the American credit counselling agency known by the same name. For the website of the American CCCS, see http://www.consolidatedcredit.org/?t=t8mdsp; the website of the Canadian CCCS is http:/www.consolidatedcredit.ca/?partnerid $=1000$. We have been unable, however, to confirm this relationship.
} 
interaction with any GTA community; that is, they may be not-for-profits but they are not community-based. ${ }^{15}$

One consequence of the increased competition has been an advertising battle waged on GTA buses and subways, and on the internet. CCCS reported spending $\$ 1.2$ million on advertising, closely followed by IDS at $\$ 1.1$ million and Credit Canada at $\$ 800,000 .^{16}$

According to the T3010 forms that all registered charities are required to file with the Canada Revenue Agency, Credit Canada has now fallen to the third position among Canadian not-forprofit CCA. The biggest agency, as measured by the size of revenues, is now CCCS which listed revenues of $\$ 6.5$ million for the fiscal year ending in October 2010. IDS is second with reported revenues of $\$ 5.4$ million at the end of calendar 2009. At the same time, Credit Canada reported revenues of $\$ 4.5$ million.

Outside of Ontario, the industry developed more slowly. According to Margaret Johnson, one of its founders, the Credit Counselling Society of British Columbia (CCCSBC) arose in 1996 from the interest of the Credit Grantors Association of Vancouver in the credit counselling model that was then in place in Ontario. ${ }^{17}$ Johnson and Scott Hannah, who would later be appointed as the executive director of the new agency, were hired by the Credit Grantors Association to go to Toronto to observe the operations of CCSMT and to talk with two of its principals, Duke Streiger and Laurie Campbell.

Armed with an initial contribution of \$250,000 from the Credit Grantors Association, the Credit Counselling Society soon began operations. On November 8, 1996, the Vancouver Sun announced the opening of the first CCCSBC office. According to Scott Hannah, its first and only director, CCCSBC aimed to "... complement government programs and provide an alternative to private credit counselling services which may charge substantial fees." ${ }^{18}$ The new not-for-profit agency would receive "the bulk of its funding from banks, credit unions and credit card issuers." Operationally, the Society was funded by a contribution of $25 \%$ of all money collected for the banks and $15 \%$ of all funds collected for finance companies, retailers and other creditors. In addition, debtors using the services of the Society paid the Society $10 \%$ of all monies paid to their creditors, up to a maximum of $\$ 50$ per month. ${ }^{19}$

\footnotetext{
${ }^{15}$ The Congressional Report on abuses by the US credit counselling industry entitled "Profiteering in a Not-forprofit Industry" distinguished between "old school" credit counsellors that had been community-based and "new school" credit counsellors that lacked any such base. See US, Profiteering in a Not-for-profit Industry: Hearing Before the Permanent Subcommitte on Investigation, 108th Cong (24 March 2004), online: Senate Committee on Homeland Security and Governmental Affairs

$<$ http://hsgac.senate.gov/public/index.cfm?FuseAction=Hearings.Hearing\&Hearing_id=35837baf-2e06-4ab6-95fa$624 \mathrm{fbf} 2 \mathrm{aae} 76>$.

${ }^{16}$ The current paragraph and the following one are based on the T3010 forms filed by the CCA mentioned. These forms for each CCA are available online: Canada Revenue Agency, Charities Listing $<$ http://www.craarc.gc.ca/chrts-gvng/lstngs/menu-eng.html>.

${ }^{17}$ E-mail communication with Margaret Johnson, President, Solutions Credit Counselling Service (10 July 2011).

${ }^{18}$ Michael Kane, "Credit advisors open office in Royal City" Vancouver Sun (8 November 1996) Presumably, the government program to which CCCSBC was a complement was the BC Debtor Assistance program, discussed below.

${ }^{19}$ Ibid.
} 
The Credit Counseling Service of Alberta (CCSA) was a not-for-profit organization established in 1997 with funding from the provincial government. The new service was designed to take over the operation of Alberta's Orderly Payment of Debts (OPD) program. The province gradually removed its annual funding and CCSA became self-sufficient, in part by charging for personalized financial counselling.

The most recent development in this industry was a change in the method by which the major banks funded the CCA. Under an agreement administered by the Canadian Bankers Association, the major banks had established a standard "fair share" - a percentage of debtor repayments that the creditors return to the CCA. ${ }^{20}$ In the fall of 2009 , the creditors decided to determine the percentage that they would return to the CCA on a case-by-case basis. ${ }^{21}$

The history of credit counselling in the US will be relevant to our legal discussion below and we briefly summarize that history here. ${ }^{22}$ In the first half of the twentieth century in the US, forprofit debt-adjusters (also known as debt-poolers) negotiated with a debtor's creditors to reduce the principal owing and, after an agreement had been reached, collected payments from the debtors and passed them on to the creditors. In the 1950s, because of the high fees charged by the debt-adjusters (and other abuses), many states passed laws preventing for-profit firms from providing credit counselling, effectively banned them from the practice.

The state laws did not prevent not-for-profit organizations from providing credit counselling and, encouraged by credit granters, not-for-profit community-based credit counselling began in earnest. This 1950s development set the stage for the 1965 establishment of the Credit Counselling Services of Metropolitan Toronto which followed a similar model. Crucially, this group of American CCA were not focused primarily on developing debt-management plans, although such plans were certainly part of their operations. They provided "information to the public on budgeting, buying practices, and the sound use of consumer credit through the use of films, speakers, and publications" in the words of the Internal Revenue Service ruling that validated their not-for-profit status. ${ }^{23}$ The debt-management plans established by these CCA called for the full repayment of the principal owed but also provided for reduction in future interest payments and the elimination of some fees.

Beginning in the 1990s, a new set of not-for-profit CCA took advantage of the opportunities presented by the combination of rapidly increasing consumer debt and the development of modern communication and data processing techniques to move away from local, in-person credit counselling and toward large-scale, telephone "counselling" that was focused primarily on the establishment and administration of debt management plans. The various abuses of these "new school" credit counsellors led to a Congressional inquiry in 2004 and the revocation of the

\footnotetext{
${ }^{20}$ See the discussion of this agreement in the next section.

${ }^{21}$ Brenda Bouw, "Banks pull out of national credit counselling donation program; individual system instead that some worry will be more onerous" Canadian Press (26 August 2009).

${ }^{22}$ Leslie E Linfield, "Uniform Debt Management Services Act: Regulating Two Related - Yet Distinct - Industries" (2009) Am BankrInst J 50. Our brief history is based primarily on Linfield's vesion of that history.

${ }^{23}$ Rev Rul 69-441, 1969-2 CB115. This ruling is discussed further in a later section.
} 
not-for-profit status of many of the largest organizations. These developments are discussed in Section III (c) below.

In recent years, a new form of credit counselling, known as "debt-settlement" has become more prominent in the US. Operated on a for-profit basis, debt-settlement firms harken back to the early twentieth century practice of debt-adjusters by seeking to negotiate a reduction in the principal owed by their clients. Importantly, however, this new generation of debt-adjusters did not negotiate with the creditors in advance of repayment. Instead, they instruct their clients to stop making any debt payments in the hope of increasing the willingness of the creditors to negotiate with the debt-settlement companies. Instead of making payments to creditors, the debtors build up savings which are intended to fund a negotiated settlement. The debt settlement firms make no pretense of providing counselling services and, because of their for-profit status, there is no need for them to do so. As with the earlier set of debt-adjusters, abuses have been common. In 2008, the US Better Business Bureau listed "debt negotiation" as one of its Top Ten Scams. Debt settlement companies have arrived in Canada but have not yet become the focus of a great deal of concern. ${ }^{24}$

\section{The Retreat of Provincial Governments from Debt Advice}

At the same time as the not-for-profit credit counselling industry was evolving away from a community-based, provincially-funded social service model toward a creditor-funded business model, provincial governments were backing away from any involvement in providing remedies to people with debt problems. That involvement has taken two forms: (1) administering Orderly Payments of Debts (OPD) programs, first under provincial laws and, after 1966, under Part X of the Bankruptcy and Insolvency Act; and (2) operating debt advice services. Each of these will be discussed in turn.

\section{Orderly Payment of Debts}

Part X of the Bankruptcy and Insolvency Act ("BIA") gives provinces the option of administering an OPD program that allows debtors to pay all of their debts over a four year period with future interest limited to $5 \%{ }^{25}$ At one time, six provinces - British Columbia, Alberta, Saskatchewan, Manitoba, Nova Scotia and Prince Edward Island - operated OPD programs. British Columbia (in 2002), Manitoba (in 1995) and Prince Edward Island (in 2007) have since dropped their OPD programs. Only Alberta, Saskatchewan and Nova Scotia continue to offer OPD programs.

\footnotetext{
${ }^{24}$ The study of debt settlement companies in Canada is beyond the scope of this article. For an example of a Canadian debt settlement company, however, see http://www.ccdr.ca/.

${ }^{25}$ R.S.C. 1985, c.B-3; See Jacob Ziegel "The Philosophy and Design of Contemporary Bankruptcy Systems: A Canada-United States Comparison" (1999) 37 (2) at 250 "Part X of the BIA has its genesis in orderly payment of debts legislation adopted in Manitoba during the Depression, and subsequently copied in Alberta. The Supreme Court of Canada held the legislation ultra vires the provinces in a 1960 decision as an encroachment on the federal government's exclusive insolvency jurisdiction. This forced the federal government to introduce legislation of its own, and it did so in 1966 by adding Part X to the BIA. Part X only applies to those provinces that have elected to adopt it; only six provinces have done so. Andrew Dekany, Consumer Debt Counselling in Canada (Osgoode LLM Thesis; 1999) argues at page 34 that the six year gap, between 1960 and 1966, when OPD was unavailable as a debt resolution option "provided an opportunity for the private business sector in Ontario to enter that field."
} 
Saskatchewan's Provincial Mediation Board came into existence 80 years ago, with wide-ranging power in relation to debt. Historically, the board dealt predominantly with farm debt, attempting to help people to keep their farms. Currently, the Board's Credit Counselling and Debt Management Services office deals with Section X of the $B I A$. The bulk of the funding (98\%) for the OPD program comes from the Government of Saskatchewan, with the remainder coming from a $15 \%$ levy on the creditor. OPD is one of the few ways to deal with student loans before an individual has been out of school long enough (seven years) to have such loans discharged through bankruptcy. Most of the OPD cases handled by the Credit Counselling and Debt Management Services office therefore involve student loans. In 2010-2011, the Credit Counselling and Debt Management Services office served 55 individuals and an additional 26 individuals signed up for OPD. ${ }^{26}$

\section{Provincial Debtor Assistance Programs}

Provincially-funded and operated debt advice services are even less common. Such services now exist in Nova Scotia and Saskatchewan and formerly existed in British Columbia. The numbers of clients currently served is quite small.

The Saskatchewan Credit Counselling and Debt Management Services program facilitates the negotiation of a debt settlement agreement between debtors and their creditors. The program looks into the claims against the debtors, assesses their ability to pay and attempts to settle the debts with the creditor. The debt counsellor we interviewed told us that she believes that "everyone who walks in the doors needs to be heard" and that she looks at people's best interests and personal situations rather than presuming that OPD is the best way to go. If it makes most sense to work out a budget rather than sign an individual up for the OPD, the debt counsellor said that she would take that approach.

Nova Scotia's Debtor Assistance program offers a variety of programs to people who are in debt and experiencing financial difficulties. ${ }^{27}$ Individuals can meet with licensed administrators, located throughout the province, who will review their situation and discuss available options. ${ }^{28}$ This advice, which includes both budget and debt counselling, is provided free of charge. ${ }^{29}$ In 2009-2010, the Debtor Assistance program met with 422 clients; 158 were referred to bankruptcy trustees, 168 were given budget counselling and 96 were classified as considering a consumer proposal. ${ }^{30}$

\footnotetext{
${ }^{26}$ Information in this paragraph was provided in a telephone conversation with Debra Moody, debt counsellor for the Government of Saskatchewan (July 28, 2011).

${ }^{27}$ See Government of Nova Scotia, Debtor Assistance, online: Service Nova Scotia,

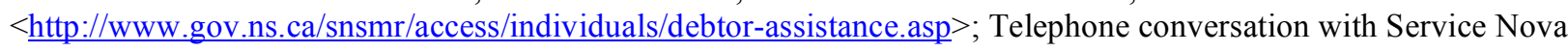
Scotia customer service representative (22 July 2011) and Coordinator of Debtor Assistance, Service Nova Scotia and Municipal Relations (25 July 2011).

${ }^{28}$ Telephone conversation with Tamara Ryan, coordinator of the Debtor Assistance Program in Nova Scotia (25 July 2011).

${ }^{29}$ Ibid.

${ }^{30}$ The numbers appearing here are based on information provided by Tamara Ryan, coordinator of the Debtor Assistance Program in Nova Scotia.
} 
British Columbia's provincially-funded Debtors Assistance Branch was set up in 1974 to take over the administration of OPD in British Columbia and to provide a range of services to heavily indebted consumers. The Branch was closed after it was included in a series of cuts to BC social programs in April, 2002. Debtors Assistance administered the provincial OPD program, administered consumer proposals under the BIA, offered debt management plans, as appropriate, and gave impartial advice and information to debtors. ${ }^{31}$ In addition, with authority conferred by the BC Debtors Assistance Act, the program could stay collections and negotiate with creditors to reduce the interest rates for debtors. Douglas Welbanks, the long-time head of the program, reported that $20-25 \%$ of the program's resources were devoted to resolving a wide range of legal disputes arising from financial transactions. Much of the remaining agency resources were used to respond to requests for information (including information concerning help with legal matters) and to deal with requests for OPD. According to Welbanks, $10-15 \%$ of clients were enrolled in OPD and 10-15\% were advised to seek bankruptcy protection. In general, Debtors Assistance was a source of both information and action on behalf of those who sought its help. Importantly, it was also a place to which other agencies (including legal aid services, family service agencies and bankruptcy trustees) could refer clients who they were unable to help.

Ontario never participated in OPD and never operated a provincial debt advice service. Similarly, Québec never participated in OPD and never operated a provincial debt advice service.

\section{The Canadian Legal Framework for the Credit Counselling Industry}

While the Canadian credit counselling industry and the corresponding regulatory framework have faced only limited scrutiny, the same cannot be said of their American counterparts. Both the American credit counselling industry (including both not-for-profit credit counsellors and for-profit debt-settlement companies) and the regulatory framework within which it operates have been described in unfavorable terms by a number of commentators:

Critics charge that credit-counseling agencies now provide no social utility and operate simply as deceptive debt collectors on behalf of creditors._Many critics also allege illegal financial improprieties related to the agencies' required use of nonprofit status. Due to the exemption of nonprofits from debt-adjuster laws, this industry remains largely unregulated. Nevertheless, the FTC [Federal Trade Commission] and state attorneys general (AGs) have pursued many enforcement actions against credit-counseling agencies for violations of state and federal consumer-protection laws. $^{32}$

\footnotetext{
${ }^{31}$ The information in this paragraph is based on a telephone conversation with Douglas Welbanks and Margaret Johnson, President of Solutions Credit Counselling Service, on August 22, 2011.

${ }^{32}$ Andrew T Schwenk, "Note Debt Settlement: A Beast of Burden without Reins" (2011) 76 Brook L Rev 1165 at 1167. See also: Roger Colinvaux, "Charity in the $21^{\text {st }}$ Century: Trending Toward Decay" (2011) 11 Fla Tax Rev 1 at 35-36, 45-49; Ryan McCune Donovan, "The Problem with the Solution: Why West Virginians Shouldn't "Settle" for the Uniform Debt Management Services Act" (2010) 113 W Va L Rev 209 at 214-32; John Hurst, "Protecting Consumers from Consumer Credit Counseling" 9 NC Bnk Inst 159 at 162-67; Thomas E Johnson, "Advising the Financially Beleaguered Client" 9 NCBNKI 159 at 30-31 (WL); Ronald D Kerridge, "Tax-Exempt Credit
} 
Mark Everson, in a press release announcing the revocation of the charitable status of 41 not-forprofit CCA representing more than 40 percent of industry revenues wrote:

Over a period of years, tax-exempt credit counseling became a big business dominated by bad actors. Our examinations substantiated that these organizations have not been operating for the public good and don't deserve tax-exempt status. They have poisoned an entire sector of the charitable community. ${ }^{33}$

As in the American situation, Canadian legislation was not designed with reference to the current credit counselling industry or potential consumer protection issues that arise as consumers interact with the industry in increasingly large numbers. Nonetheless, various overlapping strands of provincial and federal regulation may be used to address potential problems with the industry - within certain limits.

To the extent that legal concepts of general application from federal and provincial law — such as misrepresentation or breach of fiduciary duty - may apply, they require litigation to be initiated by a consumer of credit counselling services. The usual limits of litigation exist in this situation: lack of resources, knowledge and an organized group of debtors to move forward with the claims. It is notable that as a response to such limits, a number of American class actions have been initiated and settled, but to our knowledge no such action has been undertaken in Canada. While Canadian regulators, including the Canada Revenue Agency and the Competition Bureau have an ability to monitor the industry and take action. it is unclear whether the not-forprofit credit counselling industry is on the radar of either regulator. Note that the industry was not on the radar of the IRS until the 2004 Congressional hearings focused on the industry.

In this section, we briefly set out the regulatory framework that may touch on CCA. First we consider two concepts of more general application from tort and contract law: misrepresentation and breach of fiduciary duty. Next, we consider the use of "not-for-profit status" as provided for under the Income Tax Act. Last, we consider the regulation of CCA as collection agencies. We do not reach any conclusions on the application of these various concepts to Canadian CCA currently in operation, but instead describe the concepts in a coordinated way with a view to

Counseling Organizations and the Future of Debt-Settlement Services" 14 Tex Rev L and Pol 343 at 350-54; Lea Krivinskas, "Don't File: Rehabilitating Unauthorized Practice of Law-Based Policies in the Credit Counseling Industry" (2005) 79 Am Bank LJ 51 at 51; Leslie E Linfield, "Credit Counseling Update: The "Perfect Storm" Brewing” (2005) 24 Apr Am Bankr Inst J 30; Leslie E Linfield, "Consumer Credit Counseling Reform: The Good, the bad and the ugly" (2004) 23 Nov Am Bankr Inst J 14 at 14; Leslie E Linfield, "Uniform Debt Management Services Act: Regulating Two Related - Yet Distinct - Industries” (2009) Am Bankr Inst J 50 at 60; Derek S Witte, "The Bear Hug That is Crushing Debt-Burdened Americans: Why Overzealous Regulation of the Debt-Settlement Industry Ultimately Harms the Consumers It Means to Protect” (2010) Tex Rev L and Pol 277 at 292-95; Carla Stone Witzel, "The New Uniform Debt-Management Services Act" (2006) 60 Cons Fin LQ Rep 650 at 650.

${ }^{33}$ Nonprofit Credit Counseling Organizations: Hearing Before the S. Comm. On Oversight Comm. On H. Ways \& Means, 108th Cong. (2003) (statement of Mark Everson, Commissioner, Internal Revenue Service) cited in Ronald D Kerridge and Robert E Davis, "Tax-Exempt Credit Counseling Organizations and the Future of Debt-Settlement Services" (2010) 14 Tex Rev L and Pol 343. 
beginning to outline the existing framework for the regulation of the credit counselling industry. In doing so, we draw from the American regulatory experience. The goal for this exercise is to provide context for ongoing assessments of both the industry and the ability of the existing regulatory framework to deal with potential problems within the industry.

\section{a. Misrepresentation}

\section{i. $\quad$ Competition Act}

In conjunction with provincial consumer protection legislation, Part VI of the Competition Act $^{34}$ prohibits businesses from making false representations. The term "misleading advertising" describes a situation in which "a claim about a product or service is materially false or misleading, in an attempt to persuade the consumer to buy it." 35 To date, we are not aware of any actions against CCA on the basis of the Competition Act or similar provincial consumer protection legislation. In contrast, on the basis of similar legislation, actions have been settled or litigated in the United States for false and misleading representations by CCA on the following issues:

i. up-front fees;

ii. the implications of a debt management plan ("DMP") for a debtor's

credit rating;

iii. the debts that are covered by a DMP;

iv. that the CCA teaches consumers how to handle credit and finance in the future; and

v. that the CCA is a not-for-profit entity.

For example, the case of Alyssa Polacsek et al v Debticated Consumer Counseling Inc et al ${ }^{36}$ involved a settlement stemming from allegations that not-for-profit tax-exempt CCA brought DMP business into a for-profit business, thereby generating "private benefits" in violation of the CCA's tax-exempt statuses. ${ }^{37}$ Without tax-exempt status, the CCA were found to infringe the Credit Repair Organizations Act by obtaining fees prior to providing services and by neglecting to afford necessary disclosures, "contract language" and rights to withdraw mandated by the Act. ${ }^{38}$ It is important to note that pursuant to United Cancer Council v Commissioner of Internal Revenue, the Internal Revenue Service ("IRS") may revoke the not-for-profit status from not-forprofit organizations whose earnings inure to a private party. ${ }^{39}$

In a different example, Laverne Jones Stacey Ness and Kerry Ness et al v Genus Credit Management Corporation et al involved CCA accused of violating consumer protection laws by

\footnotetext{
${ }^{34}$ Competition Act, RSC 1985, c C-34, s 52(1).

${ }^{35}$ Industry Canada, Canadian Consumer Handbook 2008-2009, online: Canada's Office of Consumer Affairs

$<$ http://www.ic.gc.ca/eic/site/oca-bc.nsf/eng/ca02374.html>.

${ }^{36}$ Case No 8:04-cv-00631PJM (2005), United States District Court, Maryland, Southern Division, online:

$<$ www.polacsekclass.com/pdfs/DCC_NOT_web_050618.pdf>.

${ }^{37}$ Ibid.

${ }^{38} \mathrm{Ibid}$.

${ }^{39}$ Case No 98-2181 and 98-2190 (1999), United States Court of Appeals for the Seventh Circuit; 26 CFR 1.501(a)1(c), (c)(3)-1(d)(1)(i) (2004).
} 
claiming, without providing necessary disclosures, that DMPs would improve credit, credit ratings and eliminate late fees. ${ }^{40}$

Similarly, in McGraw v Cambridge Credit Counseling Corp, the West Virginia Attorney General secured a settlement in favour of consumers who were charged an up-front fee that was not used to pay off the consumer's debt and a monthly service fee of $10 \%$ in relation to DMP services, violating West Virginia's "debt pooling" statute which prohibits charging fees higher than $7 \% .{ }^{41}$ Two similar cases were settled by the West Virginia Attorney General, specifically McGraw $v$ Debt Mgmt Credit Counseling Corp ${ }^{42}$ and McGraw v Help Ministries d/b/a Debt Free. ${ }^{43}$ Both cases involved CCA that charged monthly service fees in excess of 7\%. One entity - Debt Free - charged a one-time "set-up" fee that was not distributed to creditors and charged other illegal fees, including a monthly fee for "funds handling", a fee for "credit education", and an "administrative fee of $\$ 20.00$ for failed electronic debits". ${ }^{44}$

In an example involving a debt-settlement company, in State of Texas v CSA-Credit Solutions of Am Inc, the Texas Attorney General alleged that more than $80 \%$ of the debts serviced by a CCA were not settled. ${ }^{45}$ A final example, also involving a for-profit debt settlement firm, comes from an action filed by the New York Attorney General against Nationwide Asset Services Inc (NAS), where the court found that NAS customers were promised a 25 to 40 per cent reduction in their outstanding debt, which did not materialize. Customers experienced both harassment from creditors and the destruction of their credit ratings. ${ }^{46}$ NAS was ordered to pay restitution to 180 consumers who completed the program but paid more in "fees and settlements" than the amount of their debts. ${ }^{47}$

\footnotetext{
${ }^{40}$ Case No. 1118100295 (2010), Class Action and Commercial Arbitration Tribunal, online:

$<$ http://www.adr.org/sp.asp?id=29365>.

${ }^{41}$ State of West Virginia, Office of the Attorney General, Press Release, "Attorney General Secures Settlement Agreement With Cambridge" (25 May 2006) online: West Virginia Office of the Attorney General $<$ http://www.wvago.gov/press.cfm?ID $=35 \& \mathrm{fx}=$ more $>$.

${ }^{42}$ State of West Virginia, Office of the Attorney General, Press Release, "McGraw Recovers Nearly \$92,000 in Overcharges" (31 January 2006) online: West Virginia Office of the Attorney General < http://www.wvago.gov/press.cfm?ID=62\&fx=more>.

${ }^{43}$ State of West Virginia, Office of the Attorney General, "Attorney General McGraw Secures Settlement With Debt Free" (13 September 2006) online: West Virginia Office of the Attorney General <

http://www.wvago.gov/press.cfm?ID=83\&fx=more $>$.

${ }^{44}$ Ibid.

${ }^{45}$ Case No. D-1-GV-09-000417, 261 st District Court, Travis County, Texas as cited in Ryan McCune Donovan, "The Problem With The Solution: Why West Virginians Shouldn't "Settle" For The Uniform Debt Management Services Act" (2010) 113 W Va L Rev 209 at FN123.

${ }^{46}$ See Andrew T Schwenk, "Note Debt Settlement: A Beast of Burden without Reins" (2011) 76 Brook L Rev 1165 at 1178; See also State of New York, Office of the Attorney General, Press Release, "Attorney General Cuomo Obtains Court Order Barring Debt Settlement Company That Ripped Off Thousands of NY Consumers from Operating in NYS Unless It Meets Strict Requirements" (15 October 2009) online: New York Office of the Attorney General

$<$ http://www.ag.ny.gov/media_center/2009/oct/oct15b_09.html $>$.

${ }^{47}$ Ibid.
} 


\section{ii. $\quad$ Provincial Consumer Protection Legislation}

Provincial consumer protection laws govern all sectors of commercial activity. ${ }^{48}$ Insofar as credit counselling services are considered commercial activity, or the entities offering these services are considered merchants, credit counselling is subject to the provincial laws governing commercial activity. ${ }^{49}$ While provincial consumer protection legislation varies from province to province, the provisions applicable to CCA are similar and govern similar representations to those noted above as running counter to the section VI of the Competition Act. In particular, the provincial legislation would be applicable to CCA inducing debtors to enter into contracts for the purchase of DMPs for the purported purpose of reducing their debts, improving their credit rating and providing them with credit counselling if such services do not occur. Promotional materials, and in the case of not-for-profit CCA, Canada Revenue Agency filings assert that CCA will offer budget counselling and teach consumers about finances and how to handle debts. If instead CCA enroll most of their clients in DMPs and their dealing with consumers consist of describing the DMPs and inducing consumers to enroll in such plans, this could be considered a misrepresentation under provincial consumer protection legislation.

\section{b. $\quad$ Fiduciary Duty}

Organizations have a fiduciary duty towards their stakeholders. The fiduciary principle is a natural law principle that has become a part of the Anglo-American legal tradition. ${ }^{50}$

The classic statement by Professor A.W. Scott explains the principle as follows: "A fiduciary is a person who undertakes to act in the interests of another person. ${ }^{.11}$ In most fiduciary relationships, "the fiduciary is afforded control over some aspect of the life or property of another (the beneficiary) with the expectation that the fiduciary will exercise that control for the benefit of the beneficiary." ${ }^{52}$ This principle underlies the duties of loyalty, good faith and care that apply to corporate directors and officers. ${ }^{53}$ The concept is embedded through the provincial and federal corporate law statutes in a similar fashion. ${ }^{54}$

A significant feature of the legal landscape surrounding not-for-profit CCA in Canada is the relationship between the so-called "big five" banks in Canada and the CCA. As noted above, the Canadian Bankers Association (the "CBA") had, until 2009, managed a "unified donation" policy, agreed to by each of the five banks, where each of the banks "donated" $22 \%$ of the amount the CCA collected for them back to the CCA. The CBA has made clear to us that they

\footnotetext{
${ }^{48}$ L'union des Consommateurs, "Practice and Ethics of Budget Counselling" (Research Project Final Report Submitted to Industry Canada's Office of Consumer Affairs) by Luc Rochefort and Me Marcel Boucher (2006) at 28 online: L'union des Consommateurs $<\mathrm{http}: / / \mathrm{www}$.consommateur.qc.ca/union-desconsommateurs/docu/budget/practices_and_ethic_bc.pdf $>$ [Practice and Ethics of Budget Counselling].

${ }^{49}$ Uribe and Tait, supra note 1 at 19.

${ }^{50}$ Joseph F Johnston Jr, "Natural Law and the Fiduciary Duties of Business Managers" (2005) 8 Journal of Markets and Morality 27.

${ }^{51}$ A W Scott, "The Fiduciary Principle" (1949) 37 Cal L Rev 539 at 540.

${ }^{52} \mathrm{Ibid}$ at 28.

${ }^{53}$ Ibid at 27.

${ }^{54}$ For example the Canada Business Corporations Act, RSC, 1985, c C-44 defines the general provision as follows: 122. (1) Every director and officer of a corporation in exercising their powers and discharging their duties shall (a) act honestly and in good faith with a view to the best interests of the corporation.
} 
will not release the details of this policy. Beginning in November, 2009 the CBA indicated that individual banks now make their own arrangements with individual CCA, arrangements that were described to us as generally quite similar to the previous "unified donation" policy. The CBA acknowledged that they had repealed the unified policy as they were concerned that the CCA had moved away from a counselling function. ${ }^{55}$ However, the CBA continues to provide a link to the two main umbrella organizations that represent various Canadian CCA on their web site and informs debtors of the services that the CBA believes are offered by the CCA. ${ }^{56}$ This, among other factors, could possibly change the traditional debtor/creditor relationship to one where there is a fiduciary duty between the bank and the debtor who consults a CCA.

A bank/debtor fiduciary duty in Canada only arises, however, under very special circumstances. ${ }^{57}$ Given the banks' support of the CCA and encouragement of debtors to use the services, it could be argued that there are special circumstances that lead debtors to place their trust and confidence in the banks and to rely on their endorsement of the CCA.

The funding structure of not-for-profit CCA arguably contributes to making this a legal grey area. ${ }^{58}$ Not only is there the potential for a fiduciary duty to arise as a result of the banks' relationships with the CCA but this relationship may give rise to disclosure requirements under provincial consumer protection legislation. Specifically, if the issue is to ascertain whether the organization offering the counselling service obtains part of its funding through a third-party creditor to whom the debtor is to make payments is (or is not) an "important fact" within the meaning of the provincial consumer protection legislation, discussed above, this must always be disclosed to the consumer (even if this does not affect the amount of debt to be repaid by the individual). ${ }^{59}$

\section{c. $\quad$ Not-for-Profit Status}

Under the Income Tax Act, ${ }^{60}$ a charitable organization is one that meets the following requirements: all its resources are devoted to charitable activities carried on by the organization itself, ${ }^{61}$ no part of its income is payable to, or is otherwise available for, the personal benefit of

\footnotetext{
${ }^{55}$ Email from Andrew Addison, Manager Media Relations, CBA (22 September 2009).

${ }^{56}$ See Canadian Bankers Association, Debt and Credit Counselling, online: $<\mathrm{http}: / /$ www.cba.ca/en/consumerinformation/40-banking-basics/505-debt-and-credit-counselling $>$. The two umbrella organizations are Credit Counselling Canada and the Canadian Association of Credit Counselling Services.

${ }^{57}$ See M H Ogilvie, "Judicial Intuition and Bank Fiduciary Obligation: Scaravelli v. Bank of Montreal” (2005) 21 BFLR 89; M H Ogilvie, "Banks, Advice-Giving and Fiduciary Obligation" (1985) 17 Ottawa L Rev 262, which stated that banks owe a fiduciary duty when giving investment advice; see also Dassen Gold Resources Ltd v Royal Bank, [1995] 1 WWR 171, 161 AR 161 at 139 where the Alberta Queen's Bench found that a fiduciary duty may be owed by a bank to a customer who is vulnerable and relies on the bank for advice, and that vulnerability and reliance is known to the bank.

${ }^{58}$ Supra note 5 at 13.

${ }^{59}$ Supra note 7, s 14(1).14.

${ }^{60}$ RSC, 1985, c 1 (5th Supp) [ITA].

${ }^{61} \mathrm{Ibid}$, s 149.1(1)(a).
} 
any proprietor, member, shareholder, trustee or settlor, ${ }^{62}$ and more than $50 \%$ of its directors, trustees, officers or like officials deal with each other and with each of the other directors, trustees, officers or officials at arm's length. ${ }^{63}$

A sampling of the T3010 filings of not-for-profit CCA across Canada reveals that some have reported their primary charitable purpose as providing family and crisis counselling, and financial counselling, ${ }^{64}$ while others also list debt management. ${ }^{65}$ Other CCA list education and debt management counselling as a primary purpose, ${ }^{66}$ and still others indicate that they help families end financial crises and solve money management problems through education, providing financial and credit related educational programs to its members, budget and credit counselling services, as well as debt management. ${ }^{67}$ To the extent that not-for-profit CCA do not in fact have these activities as their primary purpose, their not-for-profit status under the Income Tax $A c t^{68}$ might be questioned. Under section 188.1(1), ${ }^{69}$ a registered charity that is a private foundation (or is not private but the business it carries on is not related to the business of the charity) will be liable to a $5 \%$ penalty of its annual gross revenue from any business that it carries in that taxation year. Section 188.1(2) states that the penalty increases for repeat offenders. ${ }^{70}$ Furthermore, a charitable foundation that has acquired control of a corporation (if more than $50 \%$ of the corporation's issued share capital, having full voting rights under all

\footnotetext{
${ }^{62}$ Ibid, s 149.1(b).

${ }^{63} \mathrm{Ibid}, \mathrm{s} 149.1$ (c).

${ }^{64}$ See the 2010 registered charity information returns published by Revenue Canada for the following credit counselling agencies: Credit Counselling of Regional Niagara, Credit Counselling Service of Durham Region, Credit Counselling Service of Sault Ste Marie and District, Credit Counselling Service of Toronto, Credit Counselling Services of Alberta Ltd, Credit Counselling Services of Atlanta Canada Inc, Credit Counselling Services of Cochrane District, Credit Counselling Services of Newfoundland and Labrador Inc, Credit Counselling Society of British Columbia, Family and Credit Counselling Services Serving York Region, online: Canada Revenue Agency < http://www.cra-arc.gc.ca/ebci/haip/srch/advancedsearchresulteng.action? $\mathrm{n}=$ credit + counselling $\& \mathrm{~b}=\& \mathrm{q}=\& \mathrm{~s}=$ registered $\& \mathrm{~d}=\& \mathrm{e}=+\& \mathrm{c}=\& \mathrm{v}=+\& \mathrm{o}=\& \mathrm{z}=\& \mathrm{~g}=+\& \mathrm{t}=+\& \mathrm{y}=+\& \mathrm{p}=1>$.

${ }^{65}$ See the 2010 registered charity information return published by Revenue Canada for Credit Counselling Service of Simcoe County, online: Canada Revenue Agency < http://www.craarc.gc.ca/ebci/haip/srch/advancedsearchresulteng.action $? \mathrm{n}=$ credit + counselling $\& \mathrm{~b}=\& \mathrm{q}=\& \mathrm{~s}=$ registered $\& \mathrm{~d}=\& \mathrm{e}=+\& \mathrm{c}=\& \mathrm{v}=+\& \mathrm{o}=\& \mathrm{z}=\& \mathrm{~g}=+\& \mathrm{t}=+\& \mathrm{y}=+\& \mathrm{p}=1>$. ${ }^{66}$ See the 2009 registered charity information return published by Revenue Canada for InCharge Debt Solutions Canada, online: Canada Revenue Agency $<$ http:/www.cra-arc.gc.ca/ebci/haip/srch/t3010form21eng.action? $b=844341545 R R 0001 \& \mathrm{e}=2009-12-$ $31 \& n=I N C H A R G E+D E B T+S O L U T I O N S+C A N A D A \& r=h t t p \% 3 \mathrm{~A} \% 2 \mathrm{~F} \% 2 \mathrm{Fwww} . \mathrm{cra}-$ arc.gc.ca $\% 3 \mathrm{~A} 80 \% 2 \mathrm{Febci} \% 2 \mathrm{Fhaip} \% 2 \mathrm{Fsrch} \% 2 \mathrm{Fadvancedsearchresult-}$ eng.action $\% 3 \mathrm{Fn} \% 3 \mathrm{DIn} \% 2 \mathrm{BCharge} \% 26 \mathrm{amp} \% 3 \mathrm{Bb} \% 3 \mathrm{D} \% 26 \mathrm{amp} \% 3 \mathrm{~Bq} \% 3 \mathrm{D} \% 26 \mathrm{amp} \% 3 \mathrm{Bs} \% 3 \mathrm{Dregistered} \% 26 \mathrm{amp}$ \%3Bd\%3D\%26amp\%3Be\%3D\%2B\%26amp\%3Bc\%3D\%26amp\%3Bv\%3D\%2B\%26amp\%3Bo\%3D $\% 26 a m p \% 3 B$ Z\%3D $\% 26 a m p \% 3 B g \% 3 D \% 2 B \% 26 a m p \% 3 B t \% 3 D \% 2 B \% 26 a m p \% 3 B y \% 3 D \% 2 B \% 26 a m p \% 3 B p \% 3 D 1>$.

${ }^{67}$ See 2010 registered charity information return published by Revenue Canada for Consolidated Credit Counselling Services of Canada, online: Canada Revenue Agency < http://www.cra-arc.gc.ca/ebci/haip/srch/t3010form21eng.action? $b=816123749 R R 0001 \& \mathrm{e}=2010-09$ -

30\&n=CONSOLIDATED+CREDIT+COUNSELING+SERVICES+OF+CANADA\&r=http $\% 3 \mathrm{~A} \% 2 \mathrm{~F} \% 2 \mathrm{Fwww} . \mathrm{cra}-$ arc.gc.ca $\% 3 \mathrm{~A} 80 \% 2 \mathrm{Febci} \% 2 \mathrm{Fhaip} \% 2 \mathrm{Fsrch} \% 2 \mathrm{Fadvancedsearchresult-}$ eng.action $\% 3 \mathrm{Fn} \% 3 \mathrm{Dconsolidated} \% 2 \mathrm{Bcredit} \% 26 \mathrm{amp} \% 3 \mathrm{Bb} \% 3 \mathrm{D} \% 26 \mathrm{amp} \% 3 \mathrm{~Bq} \% 3 \mathrm{D} \% 26 \mathrm{amp} \% 3 \mathrm{Bs} \% 3 \mathrm{Dregistered}$ \%26аmp $\% 3$ Bd\%3D\%26amp\%3Be\%3D\%2B\%26amp\%3Bc\%3D\%26amp\%3Bv\%3D\%2B\%26amp\%3Bo\%3D\%26a mp $\% 3 \mathrm{Bz} \% 3 \mathrm{D} \% 26 \mathrm{amp} \% 3 \mathrm{Bg} \% 3 \mathrm{D} \% 2 \mathrm{~B} \% 26 \mathrm{amp} \% 3 \mathrm{Bt} \% 3 \mathrm{D} \% 2 \mathrm{~B} \% 26 \mathrm{amp} \% 3 \mathrm{By} \% 3 \mathrm{D} \% 2 \mathrm{~B} \% 26 \mathrm{amp} \% 3 \mathrm{Bp} \% 3 \mathrm{D} 1>$.

${ }^{68}$ ITA, supra note 60.

${ }^{69}$ Ibid.

${ }^{70}$ Ibid.
} 
circumstances, belongs to the foundation, or to the foundation and persons with whom the foundation does not deal at arm's length), ${ }^{71}$ the foundation is liable to $5 \%$ penalty of all dividends it received from that corporation in that particular taxation year. ${ }^{72}$

As is the case in Canada, and as discussed in Section II, one group of CCA in the United States has for many years been designated as tax exempt primarily because of their educational purpose. ${ }^{73}$ There has been substantial litigation and regulatory intervention in this context in the United States that may be considered by the Canada Revenue Agency in evaluating the not-forprofit status of the Canadian CCA.

In 1969, a significant ruling rendered by IRS set the groundwork for CCA in the United Status to operate with not-for-profit status. The IRS determined that the credit counselling organization in question "was formed to reduce the incidence of personal bankruptcy by informing the public on personal money management by assisting low-income individuals and families who have financial problems. ${ }^{74}$ In that case, the primary purpose was educational in nature, even though debt management was part of its activities. ${ }^{75}$ In the wake of that ruling, the number of CCA that obtained tax-exempt status increased until a series of development in the early $2000 \mathrm{~s}^{76}{ }^{76}$

By 2002, there was a perception that abuses by CCA were increasing. A Congressional subcommittee issued a scathing report in 2004, highlighting the practices of not-for-profit CCA that had caused considerable harm to consumers and seemed to contravene provisions of their status as tax-exempt organizations. ${ }^{77}$ At that point, the IRS began scrutinizing agencies more closely. ${ }^{78}$ In addition to revoking the not-for-profit status of some agencies, the IRS held off on issuing tax-exempt status to several organizations on the basis that there was too much emphasis on DMPs (in the wake of the Congressional report, just three of 110 agencies that applied for tax-exempt status received it). ${ }^{79}$

Further, American case law considering tax-exempt status has addressed concerns about relationship of the CCA with creditors and their loyalty to them, to the detriment of debtors. ${ }^{80}$ For example, in Credit Counseling Ctrs, Inc v City of South Portland, the Maine Supreme Judicial Court determined that the magnitude of profits generated by a CCA for creditors suggested that its business was not "conducted exclusively for benevolent and charitable

\footnotetext{
${ }^{71}$ Ibid, s 149.1(12).

${ }^{72}$ Ibid, s 188.1(3).

${ }^{73}$ Supra, note 33. In this section we rely heavily on Kerridge and Davis' work. While Kerridge and Davis focus on the question whether CCA can take on the function of for-profit debt-settlement firms, they consider broader questions about the role of not-for-profit CCA. We draw on this aspect of their work.

${ }^{74}$ Rev Rul 69-441, 1969-2 CB115.

${ }^{75}$ Ibid.

${ }^{76}$ Supra note 33 at 350 .

${ }^{77}$ Supra, note 15.

${ }^{78}$ Supra note 33 at 351.

${ }^{79}$ Ibid.

${ }^{80}$ Ibid at 352-353.
} 
purposes", or that the revenue it produced was not "purely incidental to a dominant purpose that is benevolent and charitable." 81

In the Pension Protection Act of $2006,{ }^{82}$ the U.S. Congress enacted Section 501(q) which complements IRS requirements by imposing the following additional requirements on credit counselling organizations claiming tax-exempt status : "[ $\mathrm{t}]$ he organization provides credit counseling services tailored to the specific needs and circumstances of the consumer"; " 83 " $]$ he organization provides services for the purpose of improving a consumer's credit record, credit history, or credit rating only to the extent that such services are incidental to providing credit counseling services and does not charge any separately stated fee for any such services organization"; 84 [t]he organization establishes and implements a fee policy to require that any fees charged to a consumer for its services are reasonable..."; " 85 t] has a board of directors or other governing body...that is controlled by persons who represent the broad interests of the public..."; ${ }^{86}$ and "[t] $]$ he organization receives no amount for providing referrals to others for debt management plan services, and pays no amount to others for obtaining referrals of consumers." 87

In Solution Plus, Inc v Commissioner, the Court held that Solution Plus was mainly formed to sell DMPs. ${ }^{88}$ Although the agency claimed that its primary purpose was educational and DMPs would only comprise a small amount of its services and profits, the Court held that the documents provided by the company itself suggested otherwise and ruled in favour of the IRS. ${ }^{89}$ The Court concluded that the primary activity of Solution Plus was not solely educational or for charitable purposes and that it did not function as an organization with exclusively charitable goals. ${ }^{90}$ This decision was based on the finding that the "primary activity would be to provide DMPs to the general public for a fee that it hopes to collect from its customers and from its customers' creditors."

In the case Better Business Bureau v United States, the U.S. Supreme Court ruled that "the presence of a single non-educational purpose, if substantial in nature, will destroy the exemption regardless of the number or importance of truly educational purposes". ${ }^{92}$ Selling DMPs does not serve an educational function and the IRS has noted that both courts and the IRS have not found the provision of debt resolution services to constitute a charitable undertaking. ${ }^{93}$

The American case law has thus established that the foremost question is whether debt resolution services comprise an integral part of an agency's activities. ${ }^{94}$ The key issue is whether a "non-

\footnotetext{
${ }^{81}$ Credit Counseling Ctrs, Inc v City of South Portland, 814 A.2d 458 (Maine 2003) at 463.

${ }^{82}$ Pension Protection Act of 2006, Pub L No 109-280, § 1220, 120 Stat 780, 1086-1088 (2006).

${ }^{83}$ Ibid, s. 501(q)(1).

${ }^{84}$ Ibid, s. 501(q)(3).

${ }^{85}$ Ibid, s. 501(q)(5).

${ }^{86} \mathrm{Ibid}, \mathrm{s.}$ 501(q)(6).

${ }^{87}$ Ibid, s. 501(q)(8).

${ }^{88}$ Solution Plus, Inc v Comm'r, 95 TCM (CCH) 1097 (2008).

${ }^{89}$ Ibid at para 18.

${ }^{90}$ Ibid, at paras 20, 22.

${ }^{91}$ Ibid, at para 9.

${ }^{92}$ Better Business Bureau v United States, 326 US 279, 283 (1945).

${ }^{93}$ IRS Priv Ltr Rul 200450039 (14 September 2004) as cited in supra note 33 at 357.

${ }^{94}$ Ibid.
} 
charitable activity is an integral part of an exempt purpose is thus a test of necessity: could the exempt objective be accomplished only by the activity in question?"95

The role that the IRS has taken in reviewing the activities of not-for-profit and for-profit CCA and the corresponding tests that have developed through case law for assessing the function and activities of CCA in the United States, provide useful precedents for a more activist role for the CRA with respect to the regulation of CCA in Canada. An audit of the extent to which Canadian CCA comply with their primary charitable status is needed. Based on the American jurisprudence the following questions could serve as a starting point as part of such an audit:

a. What is the relationship and loyalty of CCA to creditors as demonstrated by the funding model of the CCA?;

b. To what extent do debt resolution services comprise an integral part of the services of the CCA?;

c. To what extent are the primary activities of the CCA commercial versus educational?; and

d. To what extent are the services provided by the CCA geared to the specific needs of individual consumers and benefit the consumer - for example, in the form of a better credit record?

\section{d. Credit Counselling Agencies as Collection Agencies}

Most provincial legislation, and the case law interpreting it, defines CCA as collection agencies. The result is that they are subject to the same provincial regulation as collection agencies. L'union des Consummateurs notes: "The jurisprudence ... has established that enterprises which manage a consumer's debt repayment to his creditors, whether private businesses or not-forprofits, must be considered equivalent to collection agencies." 96 In Ontario, the Collection Agencies Act $^{97}$ governs the licensing and activities of collection agencies. Knowing contravention of one or more provisions of this statute is considered a provincial offence.

An example of how the Collection Agencies Act has been used to regulate the activities of a CCA can be found in an Ontario case decided in 2004. In that case, Renew Credit Services Canada Inc. (Renew) was accused of having engaged in debt collection without a license. The Ontario trial court held that an enterprise, whether for profit or not, that assisted a consumer in the management of his debts is considered a collection agency and accordingly must register as such pursuant to the provisions of the Collection Agencies Act. ${ }^{98}$ Furthermore, the Court held that this

\footnotetext{
9570 TC 594 (1978) at 611 as cited ibid note 33 at 359.

${ }^{96}$ Supra note 5 at 29.

${ }^{97}$ Collection Agencies Act, RSO 1990, c C.14 [CAA Ontario].

${ }^{98}$ Ontario (Ministry of Consumer and Business Services) v Gnish, 2004 ONCJ 399, [2004] OJ No 5684 [Ontario $v$ Gnish]; CAA Ontario; Supra note 97.
} 
was the case even if the organization was not in possession of the sums disbursed by the consumer for payment to his creditors:

In the client agreement, the client authorizes Renew to "assist in the arrangement and proposal of an acceptable repayment plan of the Client's debts to their creditors". In its explanatory instruction manual to clients, Renew advises: "Upon retaining our services you have given us control of your financial and credit affairs and you are not allowed to conduct any discussions or make any payment arrangements, orally or in writing without our authorization. We will handle everything on your behalf". 99

The Court went on to hold that:

Therefore it is obvious, based on its own published material, that Renew arranges for payment of money owing to another person, as set out in the definition of "collection agency" in the Act, and instructs its clients to advise creditors to contact Renew to discuss debtors' payment arrangements.

I therefore conclude that the true object of the Act and intent of the Legislature is to protect debtors by requiring that all those who deal with them register in order that the Registrar may ascertain which, if any, parts of the legislation may apply. ${ }^{100}$

The defendants, Renew Credit Services Canada Inc., Todd Alexander Gnish and Sherri Graham, were subsequently convicted for not being registered as a collection agency, and were at the same time convicted of three other related offenses. ${ }^{101}$

The Court listed this offence as follows:

Count \#4: and further that Renew Credit Services Canada Inc. and Todd Alexander Gnish and Sherri Graham, on or about the $20^{\text {th }}$ of November 2002, in the Town of Milton in the central west region and elsewhere in the province of Ontario, did commit the offence of carry on the business of a collection agency without registration by the Registrar under the Act, when they contracted with Derek Hardy, a consumer, contrary to section 4 (1) of the Collection Agencies Act, R.S.O. 1990, c. C-14, as amended, and thereby committed an offence contrary to section 28 (1) of the said Act. ${ }^{102}$

The Court held that:

The Collection Agencies Act in section 4(1) states "no person shall carry on the business of a collection agency or act as a collector unless the person is registered by the Registrar under this Act."

Section 29 of this Act states, "that a statement as to, (a) the registration or non-registration

\footnotetext{
${ }^{99}$ Ontario $v$ Gnish, ibid at para 6.

${ }^{100}$ Ontario $v$ Gnish, ibid at paras 7, 52.

${ }^{101} R v$ Renew Credit Services Canada Inc, 2005 ONCJ 524, 2005 CarswellOnt 8208.

${ }^{102}$ Ibid at para 5 .
} 
of any person; purporting to be certified by the Director is, without proof of the office or signature of the Director, admissible in evidence as proof, in the absence of evidence to the contrary, of the facts stated therein."

It is clear from the evidence that the defendants should have been registered, and they were, not as confirmed by exhibits 10,11 , and 12 . No evidence was presented to the contrary.

I therefore find that the Crown has proven the elements of this offence beyond a reasonable doubt and I find the defendants guilty of this charge before this Court, and convictions are registered. $^{103}$

The limits on collection activity just described do not apply, however, to a person employed by a member agency of the Ontario Association of Not-For-Profit Credit Counselling Services (see Appendix). The Ontario law is similar to the American legislation, which places strict regulatory standards on collection agencies' practices but exempts not-for-profit organizations from such prohibitions. ${ }^{104}$ These exemptions have been pointed to by a number of commentators as paving the way for the ills of the not-for-profit credit counselling industry in the United States. $^{105}$

\section{e. $\quad$ Conclusions}

Our review of the existing regulatory framework for the credit counselling industry in Canada suggests that regulation exists but is decentralized and underutilized. We identify four possible grounds that might justify further investigation by regulatory agencies:

- misrepresentation

- breach of fiduciary duty

- violation of the rules that not-for-profit organizations must follow

\footnotetext{
${ }^{103}$ Ibid at paras 44-47.

${ }^{104}$ For example: New York explicitly exempted from its ban what it called "budget planning" not-for-profit entities. GEN. BUS. LAW $\S 455(4)$ as cited in Andrew T Schwenk, "Note Debt Settlement: A Beast of Burden without Reins" (2011) 76 Brook L Rev 1165.

${ }^{105}$ See Andrew T Schwenk, "Note Debt Settlement: A Beast of Burden without Reins" (2011) 76 Brook L Rev 1165 at 1166-68; Roger Colinvaux, "Charity in the $21^{\text {st }}$ Century: Trending Toward Decay" (2011) 11 Fla Tax Rev 1 at 35-36; Ryan McCune Donovan, "The Problem With The Solution: Why West Virginians Shouldn't "Settle” For The Uniform Debt Management Services Act” (2010) 113 W Va L Rev 209 at 217; Derek S Witte, "The Bear Hug That is Crushing Debt-Burdened Americans: Why Overzeleous Regulation of the Debt-Settlement Industry Ultimately Harms the Consumers It Means to Protect" (2010) Tex Rev L and Pol 277 at 283-87; Ronald D Kerridge, "Tax-Exempt Credit Counseling Organizations and the Future of Debt-Settlement Services" 14 Tex Rev L and Pol 343 at 347-54; Leslie E Linfield, "Uniform Debt Management Services Act: Regulating Two Related - Yet Distinct - Industries" (2009) Am Bankr Inst J 50 at 51-61; Carla Stone Witzel, "The New Uniform Debt-Management Services Act" (2006) 60 Cons Fin LQ Rep 650 at 651-53; Leslie E Linfield, "Credit Counseling Update: The "Perfect Storm" Brewing" (2005) 24 Apr Am Bankr Inst J 30; John Hurst, "Protecting Consumers from Consumer Credit Counseling” 9 NC Bnk Inst 159 at 160-62; Lea Krivinskas, "Don't File: Rehabilitating Unauthorized Practice of Law-Based Policies in the Credit Counseling Industry" (2005) 79 Am Bank LJ 51 at 52-59.
} 
- violation of the rules governing collection agencies

Reliance on individual debtors or their lawyers to initiate a class action if there is in fact a breach of fiduciary duty, misrepresentation or a violation of the Collection Agencies Act on the part of CCA is unlikely to be effective as the only regulatory vehicle in the Canadian context. ${ }^{106}$ The American experience suggests instead that regulator-initiated activity may be a more useful method of monitoring of CCA practices. If the Competition Bureau and the Canada Revenue Agency are able to monitor the industry for misrepresentation and to ensure that the not-forprofit CCA stay true to their primary charitable purposes, this would be an important method of ensuring that CCA do not become a consumer protection problem.

In addition, legislation aimed specifically at regulating the credit counselling industry (for-profit and not-for-profit) may be considered. One model is the American National Conference of Commissioners on Uniform State Laws (NCCUSL) Uniform Debt-Management Services Act (UDMSA). Once registered, the UDMSA imposes four "pillars" on both not-for-profit and forprofit CCA:

(1) safeguarding the debtor's money;

(2) disclosing the credit counselor's relationship with and payment by creditors;

(3) requiring adequate financial education; and,

(4) requiring credit counselors to determine that a [debt-management plan] is suitable for the debtor before enrolling the debtor in [the plan]. ${ }^{107}$

Only a small number of American states have adopted the UDMSA to date; nonetheless, the legislation and its practical application may be worth considering as Canadian work on regulating the industry moves forward.

\section{Mystery Calls to Credit Counselling Agencies}

To gain insight into what services are actually available to debtors seeking help from CCA, we have used "mystery shoppers" to conduct a study of the services offered by CCA. While this study is still on-going, we report here on the general methods that we have adopted and on a selected set of results.

"Mystery shopping" is commonly used in marketing research as a way to understand how customers are being treated by retail service industries. ${ }^{108}$ The method has also been used by

\footnotetext{
${ }^{106}$ See Jasmina Kalajdzic, "Consumer (In)Justice: Reflections on Canadian Consumer Class Actions" (2011) 50 Can Bus LJ 356 at 356-375.

${ }^{107}$ See Andrew T Schwenk, "Note Debt Settlement: A Beast of Burden without Reins" (2011) 76 Brook L Rev 1165 at 1186; Carla Stone Witzel, "The New Uniform Debt-Management Services Act" (2006) 60 Cons Fin LQ Rep 650 at 653. See also: Ryan McCune Donovan, "The Problem With The Solution: Why West Virginians Shouldn't "Settle" For The Uniform Debt Management Services Act" (2010) 113 W Va L Rev 209 at 213, 233-39, 249-56; Derek S Witte, "The Bear Hug That is Crushing Debt-Burdened Americans: Why Overzealous Regulation of the Debt-Settlement Industry Ultimately Harms the Consumers It Means to Protect" (2010) Tex Rev L and Pol 277 at 296-97; Leslie E Linfield, "Uniform Debt Management Services Act: Regulating Two Related - Yet Distinct Industries" (2009) Am Bankr Inst J 50.

${ }^{108}$ See http://www.fsa.gov.uk/pubs/other/mysteryshoppingguide.pdf
} 
regulatory agencies (including the UK Financial Service Authority and the Financial Consumers Agency of Canada) to assess the quality of services received by clients of financial service organizations. ${ }^{109}$

In essence, the idea is to train research assistants to present standardized scenarios to one or more organizations and then to assess the responses of the organizations to the scenarios. The scenarios are generally designed to imply an outcome that designers believe should result and the question is whether the interaction with the organization leads to that outcome. For example, in a study of triage health services by Moriarity, McCloud and Dowell, one of the scenarios involved "a male patient with a past history of rheumatic fever calling about a sore throat" and the proper outcome was thought to be a referral to a medical practitioner. ${ }^{110}$ Three other "simulated patients" were used in the Moriarity, McCloud and Dowell study.

Our idea was to use simulated debtors to assess the advice given by CCA. Each scenario involved a debtor whose best course of action, in our opinion, would be to file for bankruptcy (or perhaps a consumer proposal). Our interest was therefore in whether this course of action was recommended. In light of the claim by CCA that they provide counselling services to their clients, a secondary interest was to ascertain the extent to which counselling was actually provided to the simulated debtors.

After receiving ethics clearance from the Research Ethics Boards of our respective universities, we developed four scenarios and trained several research assistants to be simulated debtors. The research assistants then called various CCA, including several of the largest not-for-profit CCA, recording each call. ${ }^{111}$ The calls reported on in this section are a sample of the 30 calls we conducted thus far; we will report on the full set of calls in a forthcoming article.

One simulated debtor, named "Nora", had some equity in her home but had expenses that were consistently above her income, leading to continued borrowing from a line of credit. The balance on the line of credit was $\$ 19,000$ and growing year by year. No other debts existed.

One call by Nora, to one of the "big three" CCA, lasted only 5 minutes and 31 seconds. Given Nora's simulated income and debt profile, the counsellor quickly ascertained that the monthly payment would be just over $\$ 400$ per month for three and a half years. She then asked Nora if she could afford to make such a payment; Nora said "no". The counsellor then said that the only options available to Nora would be a consumer proposal or a personal bankruptcy, suggested that Nora look up a local bankruptcy trustee in the Yellow Pages and ended the call.

\footnotetext{
109 The Financial Consumer Agency of Canada used mystery shopping as away to evaluate the service provided by its own Consumer Contact Centre. See http://www.fcacacfc.gc.ca/eng/about/planningaccountab/2007ccc/2007surccc-6-eng.asp. The Financial Service Agency used mystery shopping to investigate practices in the sale of payment protection insurance. See http://www.fsa.gov.uk/pubs/consumer-research/crpr45.pdf.

${ }^{110}$ See Helen Moriarty, Deborah McLeod and Anthony Dowell, "Mystery Shopping in Health Service Evaluation" (2003) British Journal of General Practice 942.

${ }^{111}$ Recordings and transcripts of the calls are on file with the authors.
} 
Another of the calls by Nora, to another of "big three", was far longer, lasting almost an hour. After carefully going through Nora's income and expenses, the counsellor suggested that the payment required to pay off her debts would be about $\$ 550$ per month for 48 months; such a payment would require that her budget be cut by $\$ 1,300$ per month, an unlikely possibility. The counsellor then told Nora that "her program" (i.e., the debt management plan) was not a good option.

I'm not sure that our program is the most appropriate program for you. You do have equity in the property and if we were to try and send out a proposal to [the bank] asking them to stop charging interest and to accept a payment over approximately four years, they may question why you need a program like ours if there's an ability to make the payments ... That's the creditors, not credit counselling.

To her credit, the counsellor spent about fifteen minutes going through Nora's budget after ascertaining that the DMP would not be appropriate and suggested reductions in her spending that would make her expenses, not including her existing debt payments, equal to her income.

One call from a simulated low-income debtor named "Brittany" actually involved a mistake by the research assistant. The profile was supposed to involve a lone parent with a disability and about a monthly income of about $\$ 2,300$ from two disability programs. However, the research assistant forgot to mention one of the two sources of income - a monthly $\$ 900$ payment when she called a CCA located in the Greater Toronto Area. The counsellor assumed, without being told, that the income was from the Ontario Disability Support Program (ODSP) and told Brittany that there was a statute of limitations of two years on unsecured debt in Ontario. If Brittany was to make no payments for two years, and if she referred all calls to the agency, the debt would "vanish". 112 In return for handling those calls, the agency said there would be a charge of $\$ 240$ per month, presumably to be paid from the Brittany's already inadequate income of $\$ 1,400$ per month. Brittany's experience suggests that, as was true in 1967 for the Credit Counselling Service of Metropolitan Toronto, those unable to make large enough payments to support a debt management plan are not well served, if they are served at all. ${ }^{113}$

A second question that we tried to address with our mystery shoppers was whether the counselling was intended to help the debtor or to sell debt management debt plans. The former is suggested by Nora's call in which the counsellor spent time advising her on her budget after determining that a DMP was not a good idea. Alternatively, pushing for draconian and unsustainable budget cuts would imply that the purpose of the suggestions was to sell the DMP. There is a middle ground, of course, in which reasonable reductions in expenses lead to a budget that allows for the required DMP payments.

\footnotetext{
${ }^{112}$ Each of the Canadian provinces has a Limitations Act. In Ontario, the Limitations Act, 2002, provides a basic 2 year limitation period. This means that lenders must act promptly with respect to claims or potential claims against borrowers. However, the limitation period can be renewed quite easily by any range of acts or events including part payment of a debt or any sort of acknowledgement of the debt.

${ }_{113}$ An aside: "Brittany" used her own phone to make the calls and, in the ensuing months, received weekly calls from this agency inquiring about her willingness to sign up for debt management plans of varying composition. The calls ended only after "Brittany" began strenuously objecting to their continuation.
} 
Where Nora's call illustrates the first possibility, some of the other calls implied the second. For example, used Brittany's simulated debt profile, another research assistant called an organization set up by one of the "big three" in Montreal to try to tap the Francophone market. This research assistant presented herself with both disability payments, totaling \$2,300 per month.

The counselor first collected the usual income and expenditure information, looking for very precise information about the debts. There was not much scope for reducing Brittany's expenditures but the counsellor was able to create an acceptable budget by proposing draconian cuts (eliminating almost all discretionary expenditures). If that happened, the counsellor said there was room to pay about $\$ 690$ a month for four years and thus clear the debts.

No mention was made of any other method (such as personal bankruptcy or a consumer proposal) of resolving the debt. Brittany was told that the agency would charge a $\$ 50$ set-up fee plus $10 \%$ of each month's $\$ 690$. No mention was made of the creditors paying the agency for its services. ${ }^{114}$ While the counsellor efficiently and pleasantly did the budget adjustment and figured out the DMP, no actual "counselling" was done.

All the income and expenditure profiles used in this part of the project were ones that could maintain a DMP only with severe budget cuts. Moreover, the profiles were designed so that personal bankruptcy or a consumer proposal should have been a viable option.

Our overall impression is that the "counselling" sessions consist primarily of creating a budget that will satisfy the creditors and thus make the debtor able, at least in principle, to undertake a debt management plan. That is, the counselling is ancillary to the sale of a DMP. The extent to which other options were explored varied from no mention at all (as in the case of Brittany's call to the Montreal agency) to a reasonably careful explanation of the alternatives. The modal treatment was a brief mention of personal bankruptcy accompanied by the statement that "we don't do bankruptcies" or "you don't want to do that, do you?" Consumer proposals were almost never mentioned.

We also asked a colleague in the United Kingdom to arrange a series of calls, using a common simulated profile, to the UK equivalents of the Canadian CCA (one not-for-profit service and three for-profit agencies). In addition, a call was made to the National Debtline, a not-for-profit organization funded partly by the government and partly by the private sector. The common profile was of a single male with a $£ 7,000$ credit card balance and a $£ 9,000$ bank loan. This hypothetical debtor worked in London, earning an after-tax monthly income of $£ 1,900$, and lived in Brighton.

In all cases, the pattern of the calls was similar to that observed in the Canadian calls, starting with the collection of detailed information about the caller's monthly income and expenditures. Nonetheless, the organizations differed in terms of details asked and information given, and how

\footnotetext{
${ }^{114}$ None of agencies called made their remuneration transparent; none mentioned that they received payments from creditors for each debt management plan.
} 
the debt management schemes were explained. Only three (two of the three private agencies and the National Debtline) advised that bankruptcy was an option, in addition to a voluntary debt management plan. Only one, the National Debtline, discussed costs and benefits of bankruptcy and advised the caller on how to get more information about it. Only the National Debtline counsellor advised the caller to be sure that his bank account was at a different institution to where his debts were held - and why.

The quality of counsellors varied across agencies in terms of the clarity of their explanations and the breadth of the information they provided. All reviewed debts and expenditures; all discussed debt management plans and the associated process of repayment; all notified the debtor that creditors do not have to accept offers of repayment (e.g., a DMP). But not all explained that such plans are voluntary; that is, even if the repayment plan is accepted, the agreement is not legally binding and the creditors can continue to pursue their legal options. The counsellors explicitly indicated that the creditors would require minimum repayments of between $£ 100-£ 200$ per month for an Individual Voluntary Agreement (IVA) or for the UK equivalent of a Canadian DMP, whereas the caller indicated he had only about $£ 80$ available after his expenditures. ${ }^{115}$ Only two counsellors told the debtor that there were expenditure guidelines in terms of what creditors would accept as a budget for debt management plans-guidelines which the caller was nowhere near meeting.

Only one of the counsellors, from a for-profit agency, was explicit in stating that the caller needed to re-examine his priorities, remarking: "I recommend you look at your expensescurrently social over paying debts. You have to make a decision about what's important: Is it repaying your debt or your social life?"

One counsellor to whom the caller was referred did not clearly state that the budget she was trying to construct with the caller was not based on his current expenditures, but was one that he needed to adopt in order to reduce his expenses so that she could negotiate a debt management plan with the creditors. She sounded frustrated with his unwillingness to accept the guidelines for the expenses she proposed. The caller needed to request clarification a few times and was pressured by her to agree to budget guidelines that he was not comfortable with.

Only the National Debtline counsellor explained clearly that debt management plan was a voluntary agreement that the caller could negotiate on his own rather than using an agency; she suggested that he go online and complete budget forms available there, identify how much extra income he had to pay down debt monthly, and use sample letters to creditors to make his offer of payment, including letter, budget and a payment. The counsellor explained to him that there are agencies that will do this part of the negotiation on his behalf (if he so chose), but in all cases, the result would be a voluntary agreement that has no legal standing, and he might still be taken to court by creditors. She advised him how to handle that as well. She also advised that he request

\footnotetext{
${ }^{115}$ An Individual Voluntary Agreement is a formal debt resolution mechanism that is similar in many ways to a Canadian consumer proposal. Under an IVA, a payment plan, usually lasting five years, is designed by a paid administrator. Debts remaining after five years can be discharged. A debt management plan in the UK is a voluntary arrangement that is similar to a Canadian debt management plan. See Money Advice Trust, Factsheet: 35 Options For Dealing With Your Debts online: National Debtline $<\mathrm{http}$ ///www.nationaldebtline.co.uk/england_wales/page.php?page=35_options_for_dealing_with_your_debts>.
} 
that all future correspondence between himself and creditors be in writing and that he not engage in telephone negotiations. Additionally, this was the only counsellor to really discuss bankruptcy as a credible option. She explained clearly why bankruptcy was an option and explained the costs and problems that could be associated with filing for bankruptcy.

The main lesson that we take from the UK calls is that having a source of advice (here, the National Debtline) that has no financial stake in the outcome of the call is quite important. The advice given is different and almost certainly more appropriate.

\section{The Task Force on Financial Literacy and the (non)role of the CCA.}

In March of 2011, the Task Force on Financial Literacy (TFFL) released its final report, Canadians and Their Money. ${ }^{116}$ The report focused almost exclusively on ways to improve the financial literacy of Canadians by increasing the scope of financial education in the schools and in the workplace. ${ }^{117}$ A strong secondary emphasis was to improve the information that is available to Canadians by creating a comprehensive website devoted to financial matters and undertaking a broad "public awareness" campaign. ${ }^{118}$

Australia, New Zealand, the United Kingdom and the United States all developed similar national strategies related to financial literacy before the Canadian Task Force was even appointed. ${ }^{119}$ While all of the resulting national strategies focus rather narrowly on the ways in which financial education and information can improve financial literacy, there is a crucial difference between Canada and the other countries, especially Australia, New Zealand and the United Kingdom. Unlike Canada, these countries all make publicly-funded, low-cost and impartial advice available and all have stronger, more cohesive systems for regulating the financial services industry. Canada has no analogue to the publicly-funded advice services in Australia, New Zealand and the United Kingdom. Moreover, Canadian regulation of retail financial service suppliers is weak and fragmented across federal and provincial jurisdictions. Now that the United States (which also lacks low-cost impartial financial advice) has established

\footnotetext{
116 Task Force on Financial Literacy, Canadians and Their Money: Building a Brighter Financial Future (Canada: Task Force on Financial Literacy, 2010) online: $<$ http://www.financialliteracyincanada.com/pdf/canadians-andtheir-money-1-report-eng.pdf $>$ (TFFL Report).

${ }^{117}$ TTFL Report, ibid.

${ }^{118}$ TTFL Report, ibid at 60-64.

119 The Consumer and Financial Literacy Taskforce, Australian Consumers and Money (Australia: Department of Communication, Information Technology and the Arts, 2004), online:

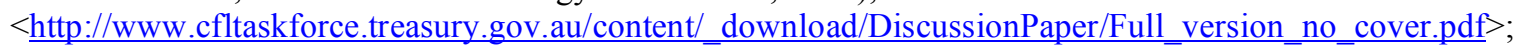
Retirement Commission, National Strategy for Financial Literacy (New Zealand: Retirement Commission, 2008), online: $<$ http://www.financialliteracy.org.nz/sites/default/files/webfm/National\%20Strategy/ns-nsfl.pdf $>$ (National Strategy for Financial Literacy); Financial Capability Steering Group, Building Financial Capability in the UK (London: The Financial Services Authority, 2004), online:

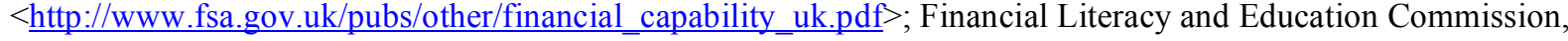
Taking Ownership of the Future: The National Strategy for Financial Literacy (Washington, DC: Financial Literacy and Education Commission, 2006), online: $<$ http://205.168.45.52/sites/default/files/downloads/ownership.pdf $>$.
} 
its federal Consumer Financial Protection Bureau, ${ }^{120}$ Canada has one of the weakest regulatory regimes among developed countries.

\section{The TFFL Recommendations}

Privileging financial education and information

The TFFL report clearly privileges the expansion of financial education as the preferred method to improve financial literacy. The importance that the TFFL attaches to financial education is evident throughout its final report. Indeed, it often seems as if the Task Force believes that financial education is a necessary and sufficient cause of financial literacy. Unfortunately, the causal link between financial education and financial literacy is not at all clear. In her TFFL background report, Yoong writes: "no strong consensus exists about the general effectiveness of financial education programs." $" 121$

Missing from the TFFL final report is any serious consideration of making low-cost impartial advice available to Canadians. Apart from recommending that the federal government "invest in the capacity of the voluntary sector to offer financial information, learning and guidance to Canadians", ${ }^{122}$ the report is silent on this issue. The current situation is that such advice is available only from a small number of community-based organizations who serve particular local communities.

Lack of Attention to the Specific Needs of the Poor

For the poor, the TFFL recommendations are punishingly inadequate. Buckland, in his excellent background report for the Task Force on the financial literacy needs of people with low-income, emphasizes that "financial literacy needs vary across the population.," ${ }^{, 23}$ The implications of this variation were lost on the Task Force, however, and none of Buckland's recommendations appear in the final report.

Overall, the TFFL recommendations are weak and self-serving. A Task Force dominated by financial service providers and financial educators has recommended little action by the financial services industry and the expansion of government funding for the services of financial educators.

Where are the Credit Counselling Agencies in the TFFL Report?

\footnotetext{
${ }^{120}$ The Consumer Financial Protection Bureau, online: < http://www.consumerfinance.gov/the-bureau $>$.

${ }^{121}$ Joanne Yoong, "Retirement Preparedness and Individual Decision Making: Implications for Canada" (Research Report prepared for the Task Force on Financial Literacy, 2010) at 34-35, online: < $\mathrm{http}$ //www.financialliteracyincanada.com/documents/consultation-2/Yoong-09-02-2011-eng.pdf $>$.

${ }^{122}$ Ibid, Recommendation 14 at 52.

${ }^{123}$ Jerry Buckland, "Money Management on a Shoestring: A Critical Literature Review of Financial Literacy and Low-income People" (Research Paper prepared for the Task Force on Financial Literacy, 2010) at 11, online: < http:/www.financialliteracyincanada.com/documents/consultation-2/Buckland-09-02-2011-eng.pdf >.
} 
The credit counselling industry is barely visible in the various reports issued by the TFFL. This is surprising for at least two reasons. First, the executive director of one of the largest and oldest Canadian CCA was a member of the Task Force; there was thus no lack of opportunity to bring the potential contributions of the CCA to the attention of the Task Force. Second, based on its view of itself, the credit counselling industry is a major source of financial education and a potential leader in any effort to improve financial literacy.

As an example of latter point of view, the submission to the TFFL by Henrietta Ross, the Chief Executive Officer of the Canadian Association of Credit Counselling Services ("CACCS", one of the three umbrella organizations formed by Canadian CCA) argues that there is a clear "fit" between the CCA and efforts to promote financial literacy. ${ }^{124}$

Our enthusiasm [for financial literacy] stems from our historical grassroots advocacy for healthy personal finances as being essential for Canadians, coupled with our deep and unique expertise in providing financial literacy training and education. Specializing in the field of financial literacy is our core competency. ${ }^{125}$

Later, Ross claims that the CACCS has been "providing personal financial education to thousands of Canadians and personal financial practitioners" 126 and recommends that the TFFL "outsource the provision and delivery of financial literacy services and the important "hands-on" training to CACCS and its network". ${ }^{27}$

Credit Counselling Canada ("CCC") competes with CACCS as one of the umbrella organizations for not-for-profit CCA. Together with its member agencies, it also claims a focus on financial education: ${ }^{128}$

Our collective approach within CCC to financial literacy and the needs of Canadians comes from many years of providing financial education on many fronts. There are few associations like CCC that have the scope of experience with Canadians across the country, from all walks of life.

And, like CACCS, it believes that it should be in the vanguard of efforts to improve financial literacy. ${ }^{129}$

\footnotetext{
${ }^{124}$ CACCS, Submission to the Task Force On Financial Literacy (2010) online:

$<$ http://www.financialliteracyincanada.com/documents/consultation/Canadian $\% 20$ Association $\% 20$ of $\% 20 \mathrm{Credit} \% 20$ Counselling\%20Services(CACCS)\%20and\%20Ross_Henrietta_329_10\%20May.pdf>.

125 Ibid at 1 .

${ }^{126}$ Ibid at 4.

${ }^{127}$ Ibid at 6-7.

${ }^{128}$ CCC, Submission to the Task Force on Financial Literacy (2010) online:

http://www.financialliteracyincanada.com/submissions/submissions-C-eng.html at 2 .

${ }^{129}$ Ibid at 3 .
} 
Credit Counselling Canada (whether through the association or through various members) must be involved in any development in a National Strategy implementation on financial literacy.

Coupled with the T3010 declarations concerning the educational goals of the CCA, the picture is one of a set of not-for-profit organizations aimed at helping all Canadians deal with debt problems and helping them learn to better handle their personal finances.

But, as our mystery calls suggest, the nature of the "training and education" is uncertain. The CACCS submission mentions the "260 counselling minutes" that are provided during the typical 48-month DMP suggesting that the counselling occurs in the context of the DMP. ${ }^{130}$ But there are also claims about thousands of people who "were provided telephone consultation", "attended preventative educational programs" or "received service outreach and delivery touch points". 131

The individual submissions of the CCA are largely about financial education and their long experience in providing it. Some, like Credit Counselling Services of Atlantic Canada, a CCC member, promote their own educational outreach efforts without mentioning their links to creditors or their focus on DMPS. ${ }^{132}$ Others present a more balanced point of view. The Credit Counselling Society of BC, another CCC member, writes: ${ }^{133}$

Not-for-profit credit counselling organizations have a mandate to educate consumers and provide solutions that will allow people to regain financial stability. However, many consumers are not aware that no /low cost credit counselling services are available to them, not only as an alternative to bankruptcy, but also for information, guidance and support as they try to get their finances back on track. Funding for our education and counselling services and programs is provided in large part by the credit granting community and creditors place tremendous value on how we are able to assist consumers.

The Task Force seems to have ignored both the CCA claims to expertise and their offers to take over Canadian financial literacy efforts. The TFFL final report barely mentions the credit counselling industry in any of its reports. The industry is mentioned in two paragraphs of the final report with a cryptic recommendation that "Canadians must be better informed about the services offered by CCA and the differences between the not-for-profit and for-profit agencies involved." 134 After studying this industry for some time, we are uncertain about these services and differences. The only other mention of the industry is as a "stakeholder" in financial literacy efforts. $^{135}$

\footnotetext{
${ }^{130}$ Supra note 121 at 3.

${ }^{131}$ Ibid at 2.

${ }^{132}$ CCS of Atlantic Canada. Submission to the Task Force On Financial Literacy (2010) online: http://www.financialliteracyincanada.com/submissions/submissions-C-eng.html ; Money Mentors. Submission to the Task Force On Financial Literacy (2010) online:

http://www.financialliteracyincanada.com/submissions/submissions-M-N-eng.html.

${ }^{133}$ CCS of BC. Submission to the Task Force On Financial Literacy (2010) online: http://www.financialliteracyincanada.com/submissions/submissions-C-eng.html. Unpaginated.

${ }^{134}$ Supra note 116 at 22-23.

${ }^{135}$ Ibid at 25.
} 


\section{Conclusion}

The credit counselling industry in Canada consists of a variety of businesses, both for-profit and not-for-profit, whose fundamental activity is setting up arrangements that allow debtors to repay some of their debts - mainly credit card debts - at lower post-arrangement interest rates than they would otherwise face. The CCA make the arrangement, the debtors make a single monthly payment to the CCA and the CCA divides up the debtor's payment among the creditors. In return for their work, the CCA are paid by both the creditors and the debtors. From the creditors, they receive a percentage of whatever the debtors' pay to the creditors, generally on the order of $20 \%$. From the debtors, they ask for about $10 \%$ of the monthly payment made to the creditors.

The "credit counselling" component of the industry is always secondary to the establishment of DMPs but, even then, is sometimes almost non-existent. While some CCA will provide free advice to debtors, most limit their counselling to the budgeting that is necessary to establish and maintain a debt management plan. Some have facilities where debtors can interact face-to-face with staff but most now do their business entirely over the telephone and internet.

Over time, the nature of the industry has changed dramatically. In its early years, the CCA were community-based, government-funded not-for-profits. In recent years, they have become freefloating enterprises, needing only a call center and a website to carry on their work with debtors. Competition has intensified, especially in the Greater Toronto Area, but also across Canada through the internet. The competition has led to advertising expenditures in the millions of dollars for the larger CCA.

In this article, we have traced the history of the industry, suggested avenues through which regulators could ascertain whether better regulation was needed, and reported on a number of "mystery calls" to CCA. The regulatory framework within which CCA function could be used in a variety of ways to explore possible grounds on which some CCA might be violating the rules that are in place. We identify four ways in which some CCA might be violating those rules: misrepresenting what they do, not complying with their fiduciary duties, not complying with the rules surrounding not-for-profit status, and acting as collection agencies without being licensed to do so. Ascertaining whether any CCA are in violation of existing rules would take some time and require action by a variety of regulatory agencies.

Another avenue for better regulation would be to require a licensing system for CCA. Douglas Welbanks, the former director of British Columbia's Debtor Assistance Branch, believes that provincial licensing authorities for not-for-profit and for-profit credit counselors should enact clearly defined provisions regulating all of their activities including the setting of reasonable fees charged debtors and creditors. He thinks that high standards for ethical conduct and a thorough 
qualifying examination for the credit counsellors would further protect and uphold the public interest. No such requirements are now in place. ${ }^{136}$

Ultimately, we believe that there is a need for low- or no-cost neutral debt advice. In this paper, we do not reach a conclusion as to whether not-for-profit CCA should be providing this advice, but we doubt that the existing situation is in the best interests of low-income debtors.

\section{$\underline{\text { Appendix }}$}

\footnotetext{
${ }^{136}$ Telephone conversation with Douglas Welbanks and Margaret Johnson, President of Solutions Credit
} Counselling Service, on August 22, 2011. 
Competition Act

\section{Part VI: OFFENCES IN RELATION TO COMPETITION}

\section{False or misleading representations}

52. (1) No person shall, for the purpose of promoting, directly or indirectly, the supply or use of a product or for the purpose of promoting, directly or indirectly, any business interest, by any means whatever, knowingly or recklessly make a representation to the public that is false or misleading in a material respect. ${ }^{137}$

\section{Consumer Protection Act (Ontario)}

\section{PART III}

\section{UNFAIR PRACTICES}

\section{False, misleading or deceptive representation}

14. (1) It is an unfair practice for a person to make a false, misleading or deceptive representation.

Examples of false, misleading or deceptive representations

(2) Without limiting the generality of what constitutes a false, misleading or deceptive representation, the following are included as false, misleading or deceptive representations:

14. A representation using exaggeration, innuendo or ambiguity as to a material fact or failing to state a material fact if such use or failure deceives or tends to deceive.

$\ldots$

16. A representation that misrepresents the purpose of any charge or proposed charge.

Unconscionable representation

15. (1) It is an unfair practice to make an unconscionable representation.

\section{Same}

(2) Without limiting the generality of what may be taken into account in determining whether a representation is unconscionable, there may be taken into account that the person making the representation or the person's employer or principal knows or ought to know,

(a) that the consumer is not reasonably able to protect his or her interests because of disability, ignorance, illiteracy, inability to understand the language of an agreement or similar factors;

(b) that the price grossly exceeds the price at which similar goods or services are readily available to like consumers;

\footnotetext{
${ }^{137}$ Ibid.
} 
(c) that the consumer is unable to receive a substantial benefit from the subject-matter of the representation;

(d) that there is no reasonable probability of payment of the obligation in full by the consumer;

(e) that the consumer transaction is excessively one-sided in favour of someone other than the consumer;

(f) that the terms of the consumer transaction are so adverse to the consumer as to be inequitable;

(g) that a statement of opinion is misleading and the consumer is likely to rely on it to his or her detriment; or

(h) that the consumer is being subjected to undue pressure to enter into a consumer transaction. ${ }^{138}$

\section{Collection Agencies Act (Ontario)}

\section{Definitions}

1. (1) In this Act,

"collection agency" means a person other than a collector who obtains or arranges for payment of money owing to another person, or who holds out to the public as providing such a service or any person who sells or offers to sell forms or letters represented to be a collection system or scheme;

"collector" means a person employed, appointed or authorized by a collection agency to collect debts for the agency or to deal with or trace debtors for the agency;

\section{Registration}

\section{REGISTRATION}

4. (1) No person shall carry on the business of a collection agency or act as a collector unless the person is registered by the Registrar under this Act.

\section{Name and place of business}

(2) A registered collection agency shall not carry on business in a name other than the name in which it is registered or invite the public to deal at a place other than that authorized by the registration.

\section{Practices prohibited}

22. No collection agency or collector shall,

${ }^{138}$ Consumer Protection Act, SO 2002, c 30, Sch A, ss 14(1), 14(2)14, 14(2)16, 15 [CPA Ontario]. 
(a) collect or attempt to collect for a person for whom it acts any money in addition to the amount owing by the debtor;

(b) communicate or attempt to communicate with a person for the purpose of collecting, negotiating or demanding payment of a debt by a means that enables the charges or costs of the communication to be payable by that person;

(c) receive or make an agreement for the additional payment of any money by a debtor of a creditor for whom the collection agency acts, either on its own account or for the creditor and whether as a charge, cost, expense or otherwise, in consideration for any forbearance, favour, indulgence, intercession or other conduct by the collection agency;

(d) deal with a debtor in a name other than that authorized by the registration; or

(e) engage in any prohibited practice or employ any prohibited method in the collection of debts.

\section{Offences}

28. (1) Every person who, knowingly,

(a) furnishes false information in any application under this Act or in any statement or return required to be furnished under this Act or the regulations;

(b) fails to comply with any order, direction or other requirement made under this Act; or

(c) contravenes this Act or the regulations,

and every director or officer of a corporation who knowingly concurs in such furnishing, failure or contravention is guilty of an offence and on conviction is liable to a fine of not more than $\$ 50,000$ or to imprisonment for a term of not more than two years less one day, or to both.

\section{Corporations}

(2) Where a corporation is convicted of an offence under subsection (1), the maximum penalty that may be imposed upon the corporation is $\$ 250,000$ and not as provided therein.

\section{Order for compensation, restitution}

(3) If a person is convicted of an offence under this Act, the court making the conviction may, in addition to any other penalty, order the person convicted to pay compensation or make restitution. ${ }^{139}$

\footnotetext{
${ }^{139}$ CPA Ontario, ibid, ss 1, 4, 22, 28(1), 28(2), 28(3).
} 
1. Section 19.1 of Regulation 74 of the Revised Regulations of Ontario, 1990 is revoked and the following substituted:

19.1 (1) The restriction in subsection 4 (1) of the Act against a person acting as a collector, unless the person is registered by the Registrar under the Act, does not apply to a person employed by an incorporated full or associate member agency of the Ontario Association of Not-For-Profit Credit Counselling Services.

(2) The following provisions do not apply to an incorporated full or associate member agency of the Ontario Association of Not-For-Profit Credit Counselling Services:

1. Section 22 of the Act.

\section{Section 11.}

(3) Section 15 does not apply to an incorporated full or associate member agency of the Ontario Association of Not-For-Profit Credit Counselling Services or to the officers or directors of that member agency. ${ }^{140}$

${ }^{140}$ O Reg 467/01, s. 1. 